\title{
Trade-off between seed number and weight: Influence of a grass-endophyte symbiosis
}

\author{
P.E. Gundel ${ }^{\mathrm{a}, \mathrm{c}, *}$, L.A. Garibaldi ${ }^{\text {b,d,e }}$, M.A. Martínez-Ghersa ${ }^{\mathrm{a}}$, C.M. Ghersa ${ }^{\mathrm{a}}$ \\ a IFEVA-Facultad de Agronomía (UBA)/CONICET, Cátedra de Ecología, Facultad de Agronomía (UBA), Av. San Martín 4453, (C1417DSE) \\ Buenos Aires, Argentina \\ ${ }^{\mathrm{b}}$ Departamento de Métodos Cuantitativos y Sistemas de información, Facultad de Agronomía (UBA), Av. San Martín 4453, (C1417DSE) \\ Buenos Aires, Argentina \\ ${ }^{\mathrm{c}}$ MTT Agrifood Research Finland, Plant protection, 31600 Jokioinen, Finland \\ ${ }^{\mathrm{d}}$ Laboratorio Ecotono, INIBIOMA-CONICET and CRUB-UNCOMA, Quintral 1250, (8400) San Carlos de Bariloche, Río Negro, Argentina \\ e Sede Andina, Universidad Nacional de Río Negro, Villegas 147, (8400) San Carlos de Bariloche, Río Negro, Argentina
}

Received 28 June 2011; accepted 21 October 2011

\begin{abstract}
Plant fitness is enhanced by resource allocation to seed number (offspring number) or weight (offspring survival). Besides, there is a well known trade-off in resource allocation between both traits. Symbiotic interactions can influence plant resource allocation to reproduction, yet little research has been performed in this direction. We studied the consequences of a grass-fungus symbiosis on the trade-off between seed number and weight, using Lolium multiflorum and the endophyte Neotyphodium occultans as our study system. In ecological terms, we experimentally removed $N$. occultans from L. multiflorum plants, and compared reproductive allocation to seed number and weight in endophyte-symbiotic vs. non-symbiotic plants at different levels of nutrient availability (small pots vs. large pots). In evolutionary terms, we compared reproductive allocation between symbiotic vs. non-symbiotic plants for different host genotypes. All plants showed a negative association between seed number and weight, once standardized for total reproductive biomass. Under high nutrient availability, endophyte-symbiotic plants showed higher seed weight than non-symbiotic plants for any seed number. However, no differences were observed under low nutrient availability. Endophyte influence also varied according to L. multiflorum genotype; specifically, endophyte-symbiotic plants showed a lower slope in the relationship between seed number and weight than non-symbiotic plants for the 'Marshall' genotype but no endophyte influence was found for the "Pampean" genotype. The results implied a higher plasticity in seed weight and lower plasticity in seed number for symbiotic plants. Indeed, endophyte-symbiotic plants showed an overall lower slope in the association between seed number and total reproductive biomass than non-symbiotic plants. Our results suggest that $N$. occultans induces heavier seeds in L. multiflorum plants under environmental conditions favorable to plant growth or for certain plant genotypes. We propose that symbiotic interactions may influence the evolution of seed number and weight trade-off.
\end{abstract}

\section{Zusammenfassung}

Die Pflanzenfitness wird durch die Allokation der Ressourcen in die Samenanzahl (Anzahl der Nachkommen) oder das Gewicht (Überlebensrate der Nachkommen) gefördert. Daher gibt es bei der Ressourcenallokation einen wohlbekannten

\footnotetext{
${ }^{*}$ Corresponding author at: IFEVA-Facultad de Agronomía (UBA)/CONICET, Cátedra de Ecología, Facultad de Agronomía (UBA), Av. San Martín 4453, (C1417DSE) Buenos Aires, Argentina. Tel.: +54 1145248070x8125; fax: +54 1145148730.

E-mail address: gundel@agro.uba.ar (P.E. Gundel).
} 
"trade-off" zwischen den beiden Eigenschaften. Symbiotische Interaktionen können die Ressourcenallokation der Pflanzen bei der Fortpflanzung beeinflussen, doch bisher wurden in diese Richtung nur wenige Untersuchungen durchgeführt. Wir untersuchten die Folgen einer Gras-Pilz-Symbiose für den “trade-off” zwischen Samenanzahl und Gewicht bei Lolium multiflorum und dem Endophyten Neotyphodium occultans als Studiensystem. In ökologischer Hinsicht entfernten wir experimentell N. occultans aus den L. multiflorum Pflanzen und verglichen die reproduktive Allokation in Samenanzahl und Gewicht bei endophytischsymbiotischen vs. nicht-symbiotischen Pflanzen bei verschiedenen Graden der Nährstoffverfügbarkeit (kleine Töpfe vs. große Töpfe). In evolutionärer Hinsicht verglichen wir die reproduktive Allokation zwischen symbiotischen vs. nicht-symbiotischen Pflanzen bei verschiedenen Wirtsgenotypen. Alle Pflanzen zeigten eine negative Beziehung zwischen der Samenanzahl und dem Gewicht, wenn sie in Bezug auf die reproduktive Biomasse standardisiert waren. Bei hoher Nährstoffverfügbarkeit zeigten endophytisch-symbiotische Pflanzen eine größeres Samengewicht als nicht-symbiotische Pflanzen bei jedweder Samenanzahl. Bei geringer Nährstoffverfügbarkeit konnten jedoch keine Unterschiede beobachtet werden. Der Einfluss der Endophyten variierte auch im Zusammenhang mit den L. multiflorum-Genotypen. Genauer gesagt zeigten die endophytisch-symbiotischen Pflanzen des "Marshall"-Genotyps eine geringere Steigung bei der Beziehung zwischen der Samenanzahl und dem Gewicht als die nicht-symbiotischen Pflanzen, beim "Pampean"-Genotyp wurde jedoch kein Einfluss der Endophyten gefunden. Die Ergebnisse zeigen eine höhere Plastizität des Samengewichts und eine geringere Plastizität der Samenanzahl bei symbiotischen Pflanzen. Tatsächlich zeigten die endophytisch-symbiotischen Pflanzen insgesamt eine geringere Steigung bei der Beziehung zwischen der Samenanzahl und der gesamten reproduktiven Biomasse als nicht-symbiotische Pflanzen. Unsere Ergebnisse lassen vermuten, dass $N$. occultans unter Umweltbedingungen, die das Pflanzenwachstum fördern, oder bei bestimmten Genotypen schwerere Samen bei L. multiflorum-Pflanzen induziert. Wir vermuten, dass symbiotische Interaktionen die Evolution des "trade offs" zwischen Samenanzahl und Gewicht beeinflussen könnten.

(C) 2011 Gesellschaft für Ökologie. Published by Elsevier GmbH. All rights reserved.

Keywords: Allometric relationships; Symbiosis; Mutualism; Grass-endophyte interaction; Plant-microbe interactions

\section{Introduction}

Plant allometry has received great attention in ecology and evolutionary research since it allows to understand relationships between morphology and function through correlation analysis of organisms size and size-dependent functional traits (Harper 1977; Niklas 1994). Strongly based on genetics, allometric relationships provide valuable information about the mechanisms controlling biomass allocation patterns in plant species in response to biotic or abiotic factors (Niklas 1994; Bonser \& Aarssen 2009; Weiner, Campbell, Pino, \& Echarte 2009). Symbiotic interactions may affect plant allometric patterns at two time scales: ecologically, by influencing the host ability to acquire resources, and in evolutionary terms, by exerting selection pressure on host populations (Thompson 2005; Zhang, Zhang, Weiner, Tang, $\&$ Chen 2011). In any case, the impact of symbiotic interactions on allometric patterns in plants has been insufficiently studied.

Reproductive allometry (relative allocation to reproductive biomass) and the relationship between its components, seed number and seed size, have been extensively studied as fitness estimators (Harper 1977; Niklas 1994; Cheplick 2002; Bonser \& Aarssen 2009). The negative correlation between seed number and seed size (i.e., a trade-off) has a central role in evolutionary ecology, since it is considered an evolved adaptive relationship or fixed developmental constraint (Venable 1992; Sadras 2007). Even though large plants can - at the same time - produce a higher number and heavier seeds than small plants, when properly corrected for plant size (see Venable 1992), the negative correlation between seed number and weight among individual plants provides evidence of the trade-off between both traits (Smith \& Fretwell 1974; Venable 1992; Muller-Landau 2010). In general, a wide range of variation is usually found in seed number and a narrower range in seed weight (Venable 1992; Sadras 2007). From an evolutionary perspective, it has been pointed out that the high plasticity in seed number allows plants to adjust growth to the environmental level of resources, while seed weight above a certain value ensures offspring fitness (Sadras 2007; Muller-Landau 2010). Additionally, trade-off between seed number and size is related to tradeoff between colonization-competition ability (Sadras 2007; Muller-Landau 2010).

Interaction with symbiont micro-organisms can affect life history traits of host macro-organisms, depending on the transmission mode and on whether the nature of the interaction is pathogenic or mutualistic. Hereditary symbioses which are only transmitted from the host to the offspring should result in mutualistic relationships and, given the partners' closeness, they should have the potential for affecting the relationship between host plant traits (Thompson 2005). The endophytic fungus Neotyphodium (Family Clavicipitaceae) is an obligate systemic symbiont of cool-season grasses of the subfamily Pooideae (Clay \& Schardl 2002). The entire life of the fungus occurs within the aboveground tissues of asymptomatic host plants, passing from one generation to the next through seeds. It is considered as a mutualistic symbiosis since symbiotic plants usually show resistance to herbivores (mediated by fungal alkaloids) and tolerance to stress factors (Clay \& Schardl 2002; White \& Torres 2010). However, since the endophyte uses resources from the host 
plant, it can be costly or parasitic under limiting growth conditions (Faeth 2002; Cheplick 2007; Faeth 2009). Additionally, given that the endophyte is asexual and vertically transmitted in hermaphroditic allogamous plants, the differential gene flow rate between the partners' populations (during flower pollination) is likely to prevent the mutualism expression because of lower genetic compatibility (Saikkonen, Wäli, Helander, \& Faeth 2004; Thompson 2005).

Vertically transmitted micro-organisms may promote host asexual reproduction or female functions because gene flow associated with sexual reproduction may be a counterforce to the genetic compatibility (Saikkonen et al. 2004; Thompson 2005). However, Neotyphodium endophytes could be associated with enhanced plant sexual reproduction since seeds are the means for endophyte multiplication and spread in self-incompatible and wind-pollinated host grasses (Clay \& Schardl 2002; Saikkonen et al. 2004; Gundel, Omacini, Sadras, \& Ghersa 2010). Indeed, in annual grass species, sexual production of seeds is the only way for the endophyte to pass from one generation to the next (Gundel et al. 2010). Gene flow may promote seed production and heavier hybrid seeds (Harper 1977). Therefore, if provided with a mechanism to deal with the intrinsic host genetic variability (e.g., being genotypically generalist) and considering that larger seeds may be associated with higher plant fitness (Metz et al. 2010; Muller-Landau 2010), selection could have favored endophytes that have enhanced their own fitness by promoting seed quality (Afkhami \& Rudgers 2008; Gundel et al. 2010). Despite the fact that large seeds could have a higher rate of predation, endophyte-symbiotic seeds are endowed with a constitutive anti-herbivory mechanism mediated by fungal alkaloids (Clay \& Schardl 2002). Finally, if the endophyte was costly to host grasses under growth limiting conditions, lower production of small seeds would seem unlikely.

Considering that both resources level and host genotype are known to affect not only symbiotic interaction outcome but also allometric patterns in plants, we used these two potential conflicts in grass-endophyte symbiosis to explore the ecological and co-evolutionary effects of hereditary symbioses on the relationship between components of plant reproductive biomass. Our model system consists of a population of the annual cool-season grass Lolium multiflorum Lam., which is naturally symbiotic with the fungus Neotyphodium occultans $(\mathrm{E}+)$ and its artificially disinfected counterpart (E-). We conducted an experiment which manipulated the nutrient availability for plant growth and studied the effect of the endophyte on the relationship between seed number and reproductive biomass, and on the trade-off between seed number and seed weight in plants. On the other hand, a genetic comparison approach was used to explore the evolutionary effects of the endophyte symbiont on the same two variables, by comparing symbiotic and non-symbiotic plants that were intra- or inter-population F1 hybrids. Plant crosses within the same population and with a genetically distant second population were used to change host genetic background.

\section{Materials and methods}

\section{Study model and plant material}

We studied the symbiosis between the $\mathrm{C}-3$ grass $L$. multiflorum (Italian ryegrass) and its endophytic fungus $N$. occultans (Clay \& Schardl 2002). L. multiflorum is an annual species in temperate and Mediterranean regions with seedling emergence in autumn, plant tillering in winter and seed set in spring-early summer. The annual life cycle is advantageous for allometric analysis in plants as it allows to clearly define the end of the growing period. L. multiflorum is naturalized in grassland communities in Argentina usually presenting high level of endophyte-symbiotic plants. In 1997, seeds were hand-harvested from a naturally endophyte-symbiotic L. multiflorum population in an old successional plant community in Inland Pampa (Argentina). The endophyte was removed from half the seeds by applying fungicide triadimenol ( $\beta$-(4-chlorophenoxy)- $\alpha$-(1,1-dimethylethyl)- $1 \mathrm{H}$ 1,2,4-triazole-1-ethanol) (Baytan, Bayer, Argentina; $150 \mathrm{~g}$ a.i. $\mathrm{kg}^{-1}$ ) using slurry (Vila-Aiub, Gundel, \& Ghersa 2005). Therefore, sub-populations of naturally endophyte-symbiotic $(\mathrm{E}+)$ and disinfected (E-) seeds were used as the Pampean reference population. Both sub-populations were annually cultivated in independent but nearby $1-\mathrm{m}^{2}$ plots to prevent genetic segregation. After each growing cycle, seeds were harvested and stored at $10^{\circ} \mathrm{C}$ and dry conditions. Plants from a commercial variety of L. multiflorum (Marshall) were used for plant crossing (see below). This population was cultivated in the same environment for three generations and it was endophyte free (based on 100 evaluated seeds).

\section{Plant experiments}

Three experiments were carried out to evaluate the effect of the endophyte alone or in combination with nutrient availability and genotype, on the allometric relationship in $L$. multiflorum. The first experiment was performed in 2000 and it was aimed at evaluating the effect of the endophyte on host plant growth attributes. Three generations after the fungicide treatment, the levels of symbiotic individuals in the $\mathrm{E}+$ and $\mathrm{E}-$ sub-populations were $80 \%$ and $6 \%$, respectively. Eighteen E+ and $18 \mathrm{E}$ - plants from the Pampean population were individually grown in pots $(1.5 \mathrm{~L})$ filled with organic back soil and white sand (60/40, v/v). The experiment was conducted outdoors and pots were watered throughout the growing season. For the whole growing period (autumn to spring-early summer), the daily average temperature, relative humidity and PAR-radiation was $17.21{ }^{\circ} \mathrm{C}, 75.52 \%$ and $25.35 \mathrm{~mol} \mathrm{~m}^{-2} \mathrm{~d}^{-1}$, respectively. At the end of the growing cycle, reproductive biomass of each plant was harvested, and all the spikes per plant were counted and threshed. Three groups of 10 seeds were weighed to estimate 1000-seed weight and number of seeds.

The second and third experiments were simultaneously performed in 2005. After 8 generations since fungicide 
Table 1. Detail of the resulting subpopulations after cross-pollinating endophyte-symbiotic (E+) and non-symbiotic (E-) Pampean plants with pollen from the Pampean (P) or Marshall (M) plant populations. Number of plant crosses, number of seeds that resulted from the crosses, and the corresponding level of symbiotic individuals are reported.

\begin{tabular}{|c|c|c|c|c|c|}
\hline \multicolumn{2}{|c|}{ Parent plants } & \multirow[t]{2}{*}{ Resulting subpopulation } & \multirow[t]{2}{*}{ Number of crosses } & \multirow[t]{2}{*}{ Seeds produced } & \multirow[t]{2}{*}{ Symbiotic individuals $(\%)^{a}$} \\
\hline Female & Male & & & & \\
\hline \multirow[t]{2}{*}{$\mathrm{E}+$} & $\mathrm{P}$ & $\mathrm{E}+(\mathrm{P})$ & 21 & 396 & 95 \\
\hline & $\mathrm{P}$ & $\mathrm{E}-(\mathrm{P})$ & 20 & 240 & 5 \\
\hline \multirow[t]{2}{*}{$\mathrm{E}-$} & M & $\mathrm{E}+(\mathrm{M})$ & 14 & 188 & 95 \\
\hline & M & $\mathrm{E}-(\mathrm{M})$ & 8 & 158 & 5 \\
\hline
\end{tabular}

a 20 seeds examined under microscope.

application, the level of symbiotic individuals was $95 \%$ for E+ and $6 \%$ for E- subpopulations. The second experiment was aimed at evaluating the effect of endophyte and nutrient availability on host plant growth attributes. E+ and E- plants were grown in two different pot sizes [1.5 L (low nutrient availability), and $25 \mathrm{~L}$ (high nutrient availability)] at a rate of $\approx 9$ plants per pot $(n=3)$. By changing pot volume and maintaining plant density constant, small or large pots allowed plants to explore different levels of soil nutrients and water.

The third experiment was carried out to evaluate the effect of endophyte and plant genotype on host plant growth attributes. A year before the experiment (2004), several controlled crosses of plants were performed. Plants from the E+ and E- Pampean sub-populations were isolated at flowering with only one plant from the same population (regardless of the symbiotic status) or one plant belonging to the Marshall variety. Since L. multiflorum plants are self-incompatible and the endophyte is maternally transmitted, the symbiotic seeds produced by female parent plants are the result of cross pollination. Consequently, four sub-populations were obtained: $\mathrm{E}+(\mathrm{P}), \mathrm{E}-(\mathrm{P}), \mathrm{E}+(\mathrm{M})$ and $\mathrm{E}-(\mathrm{M})$, and the letter between parenthesis indicates the variety (Pampean or Marshall) of the male parent plant. By working with F1 seeds from the plant crosses, the endophyte symbiotic status and genetic background were controlled (Table 1). Plants of E+(P), E-(P), $\mathrm{E}+(\mathrm{M})$ and $\mathrm{E}-(\mathrm{M})$ sub-populations were grown in $1.5 \mathrm{~L}$ pots at a density of $\approx 9$ plants per pot $(n=3)$. For these two last experiments, the potting substrate was organic black soil, sand and peat-moss (50/25/25, v/v) and pots were watered when necessary. During the whole growing period for the second and third experiments, the daily average temperature, relative humidity and PAR-radiation was $17.24{ }^{\circ} \mathrm{C}, 75.68 \%$ and $23.68 \mathrm{~mol} \mathrm{~m}^{-2} \mathrm{~d}^{-1}$, respectively. At the end of the growing cycle, reproductive biomass of each plant was harvested. All the spikes per plant were counted and threshed, and three groups of 10 seeds were weighed to estimate plant yield, 1000 -seed weight and number of seeds.

\section{Data analysis}

For the first experiment, we tested the influence of reproductive biomass (quantitative), endophyte presence, and their interaction on the number of seeds per plant, using general linear models (lm function, R Software). Besides, using the residuals from the previous model, we tested the effect of endophyte presence, seed weight (quantitative), and their interaction on seed number. This method allowed us to evaluate the trade-off between seed number and size without the confounding influence of among-plant variation in total reproductive allocation (Venable 1992). Significance of effects was tested through sequential analysis of variance for all experiments (ANOVA).
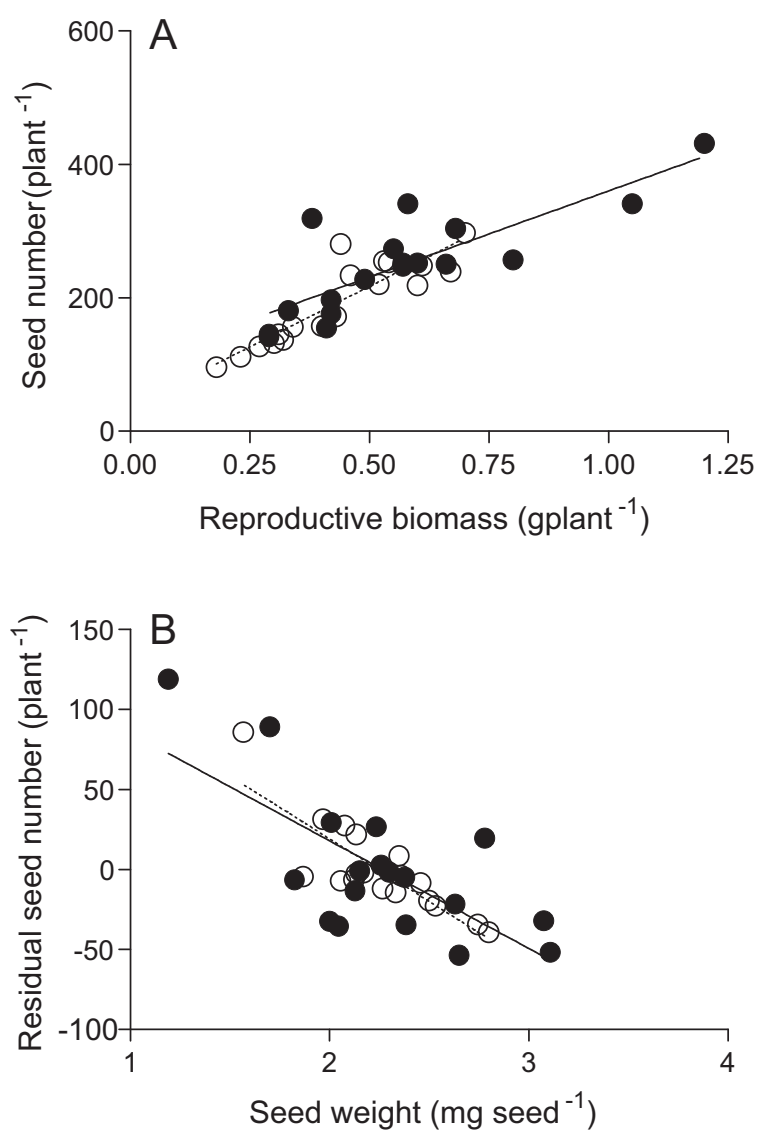

Fig. 1. Relationships between seed number and reproductive biomass (A), and residual seed number and seed weight (B) for endophyte-symbiotic $(\mathrm{E}+; \mathbf{O} ; n=18)$ and non-symbiotic $(\mathrm{E}-; \bigcirc$; $n=18)$ Lolium multiflorum plants growing individually in $1.5 \mathrm{~L}$ pots (Exp. 1). 

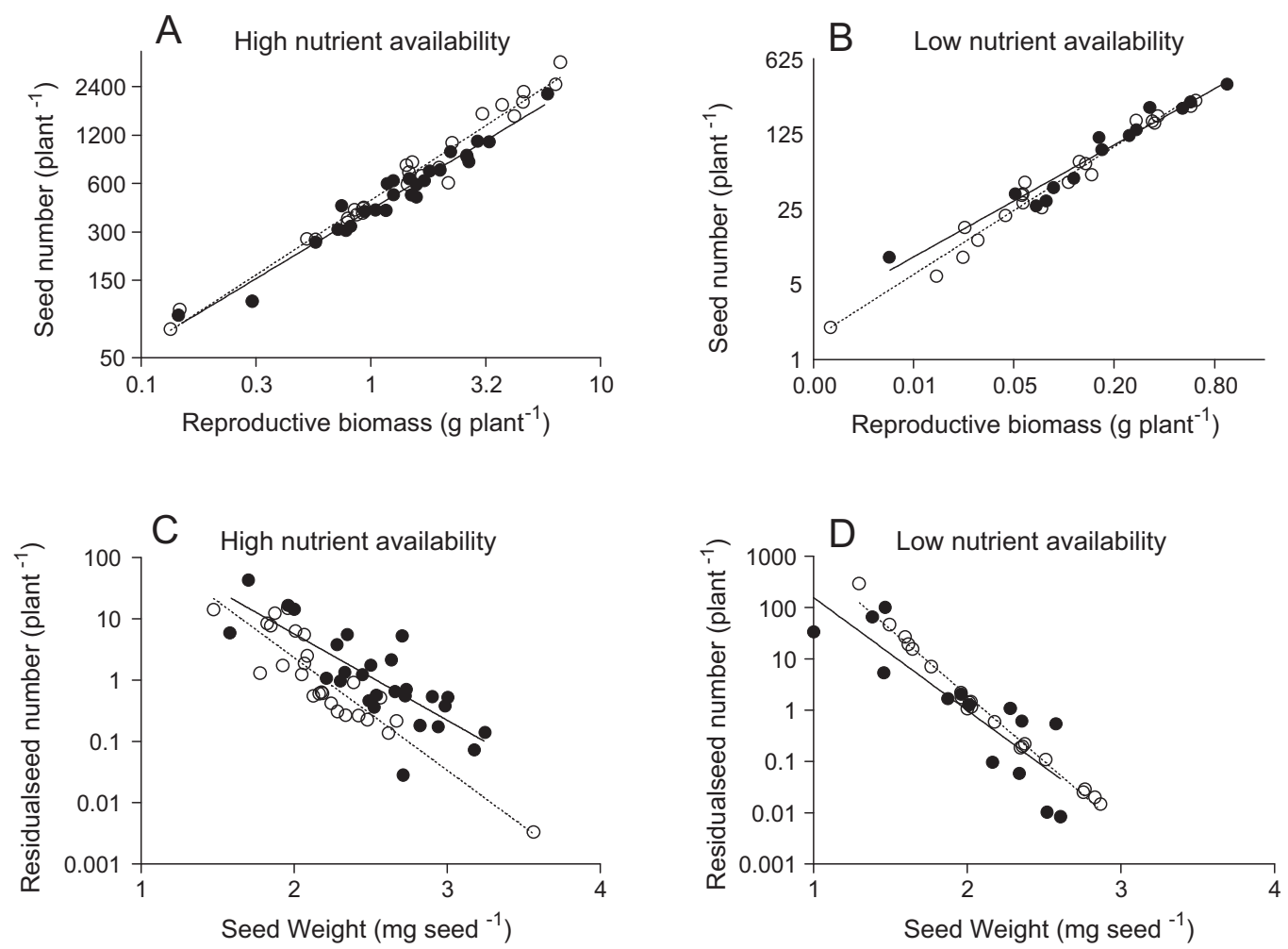

Fig. 2. Relationships between seed number and reproductive biomass (A and B), and residual seed number and seed weight (C and D) for endophyte-symbiotic $(\mathrm{E}+;-)$ and non-symbiotic $(\mathrm{E}-; \bigcirc)$ Lolium multiflorum plants growing under high $\left(\right.$ left panels; $n_{\mathrm{E}+}=27$ and $\left.n_{\mathrm{E}-}=26\right)$ or low (right panels; $n_{\mathrm{E}+}=14$ and $n_{\mathrm{E}-}=21$ ) nutrient availability (Exp. 2). Note that all axes are in $\log _{10}$ scale except for seed weight.

For the second experiment, we tested the influence of endophyte presence, nutrient availability (small or large pots), reproductive biomass, and their interaction on seed number. We further evaluated the effects of endophyte presence, nutrient availability, seed weight, and their interaction on the normalized residuals of seed number from the previous model. As individual plants were nested within pots, we used general linear mixed models considering pot as a random factor (lme function, nmle package, R Software). Seed number and reproductive biomass were $\log _{10}$ transformed to achieve normality. For the third experiment, we evaluated the influence of endophyte presence, plant genotype, reproductive biomass, and their interaction on seed number. Subsequently, another model tested the effects of endophyte presence, plant genotype, seed weight, and their interaction on residual seed number from previous model. Finally, E+ and E- plants from the Pampean population were studied (pooled) together for the three experiments, to understand endophyte presence effects for a wide range of reproductive biomass, seed number and seed weight.

\section{Results}

In the first experiment, the number of seeds showed a positive relationship with the reproductive biomass per plant
$(P<0.005)$ regardless of plant symbiotic status $(P=0.159)$ (Fig. 1A). Residual seed number per plant showed a negative relationship with seed weight $(P<0.005)$ which was also independent of plant symbiotic status $(P=0.659)$ (Fig. 1B).

In the second experiment, the magnitude of reproductive biomass was significantly higher for plants that were grown in large pots (Fig. 2). Irrespective of pot size, seed number showed a positive relationship with reproductive biomass per plant $\left(F_{1,72}=5721 ; P<0.001\right)$ (Fig. $2 \mathrm{~A}$ and B). However, the slope of this relationship was affected by the endophyte $\left(F_{1,72}=15.31 ; P<0.001\right)$. Endophyte-symbiotic plants presented a lower slope than non-symbiotic plants, 0.863 and 0.958 , respectively, which shows the change in $\log _{10}$ of number of seeds per unit increase in $\log _{10}$ of grams of reproductive biomass. A negative relationship between residual seed number and seed weight was found, which depended on both the endophyte symbiotic status $\left(F_{1,8}=9.43 ; P=0.003\right)$ and the level of nutrients $\left(F_{1,8}=18.22 ; P<0.005\right)$. For any given number of seeds, the endophyte-symbiotic plants presented heavier seeds when they were grown in large pots (Fig. 2C). This pattern vanished when plants were grown in small pots (Fig. 2D).

In the third experiment, a positive relationship between seed number and reproductive biomass per plant was also observed. The relationship was affected by plant genotype $\left(F_{1,58}=15.82 ; P<0.005\right)$ but not by symbiotic status 

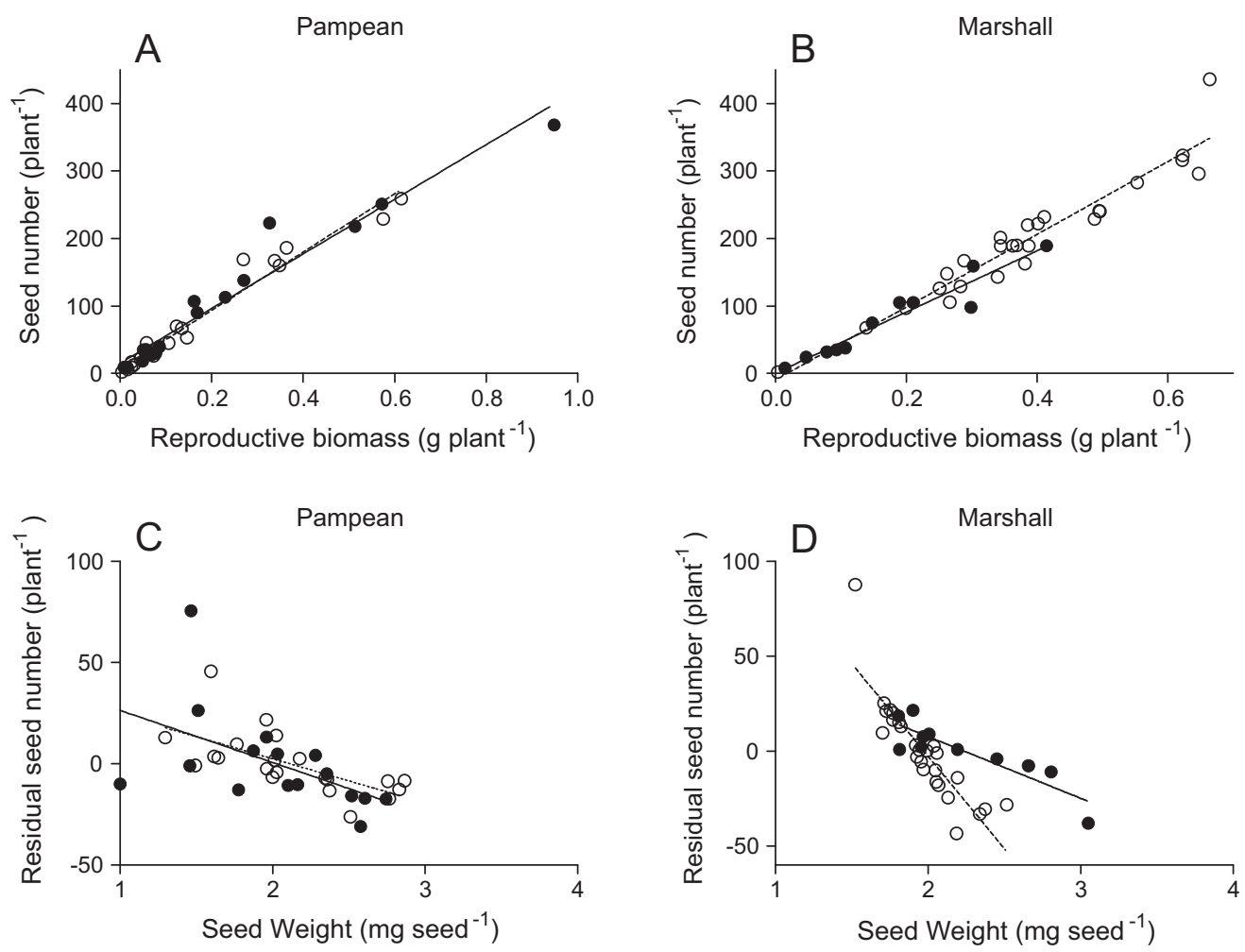

Fig. 3. Relationships between seed number and reproductive biomass (A and B), and residual seed number and seed weight (C and D) for endophyte-symbiotic $(\mathrm{E}+;-)$ and non-symbiotic $(\mathrm{E}-; \bigcirc)$ Lolium multiflorum plants of the Pampean $\left(\right.$ left panels; $n_{\mathrm{E}+}=16$ and $\left.n_{\mathrm{E}-}=21\right)$ or Marshall (right panels; $n_{\mathrm{E}+}=11$ and $n_{\mathrm{E}-}=26$ ) genotypes (Exp. 3).

$\left(F_{1,58}=1.94 ; P=0.169\right)$ (Fig. 3A and B). Marshall plants, in particular, showed a significant higher slope than Pampean plants (495.70 vs. 418.10, respectively). The relationship between residual seed number and weight was found to be dependent on the interaction effect with both the endophyte and the plant genotype $\left(F_{1,58}=13.82 ; P<0.005\right)$. The symbiotic status did not change the trade-off pattern between residual seed number and seed weight in the Pampean genotype (Fig. 3C). However, in the Marshall genotype, endophyte-symbiotic plants presented a lower slope compared to the non-symbiotic counterparts ( -32.49 and -97.31 for $\mathrm{E}+$ and $\mathrm{E}-$, respectively; Fig. 3D).

When the plants of the Pampean population from the three experiments were analyzed altogether, the positive relationship between seed number and reproductive biomass was found to be dependent on the endophyte symbiotic status $\left(F_{1}=19.01 ; P<0.005\right)$. Endophyte-symbiotic plants presented a significant lower slope (0.883) in comparison with their counterpart non-symbiotic plants $(0.975$; Fig. 4A). In a similar way, the trade-off between residual seed number and seed weight was affected by the endophyte $\left(F_{1}=28.52 ; P<0.005\right)$, where the slopes were -0.609 and -0.957 for symbiotic and non-symbiotic plants, respectively (Fig. 4B). The average seed number and its coefficient of variation were 333 and 1.03 for symbiotic plants, and 365 and 1.65 for non-symbiotic ones; while average seed weight and its coefficient of variation were 2.26 and 0.22 for symbiotic plants, and 2.17 and 0.18 for non-symbiotic ones, respectively.

\section{Discussion}

Effect of systemic fungal endophytes on host plant traits has long been recognized to affect ratios such as root/shoot ratio, or reproductive/total biomass ratio (reproductive effort) (Vila-Aiub et al. 2005; Cheplick 2007; Faeth 2009). The analysis used in our study revealed a huge phenotypic variability, typical of allogamous and wind-pollinated plant species (Harper 1977). In spite of this variability, we found that patterns in reproductive resource allocation, specifically the relationship between reproductive biomass and seed number, and the trade-off between seed number and weight, in L. multiflorum were affected by the endophytic symbiont $N$. occultans. Dependency of this result on nutrient availability and host genotype suggests ecological and evolutionary effects of the vertically transmitted fungal symbiont on host grass fitness traits.

Our experimental approach revealed that the ecological effect of the vertically transmitted symbiont largely depended on plant biomass. Since reproductive biomass reflects the environmental conditions experienced by plants in the course of the growing cycle (Harper 1977; Cheplick 2002), our results clearly match the previous ones 

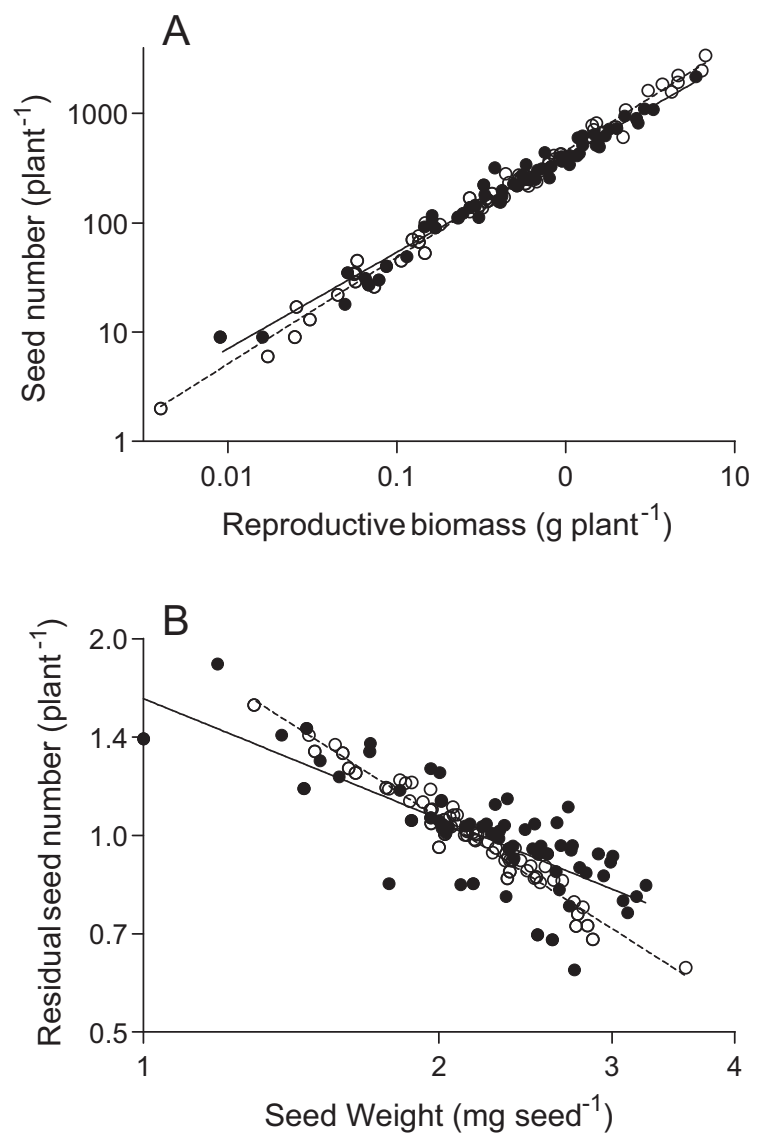

Fig. 4. Relationships between seed number and reproductive biomass (A), and residual seed number and seed weight (B) for endophyte-symbiotic $(\mathrm{E}+; \mathbf{O} ; n=75)$ and non-symbiotic $(\mathrm{E}-; \bigcirc$; $n=82$ ) Lolium multiflorum plants pooled from the three experiments. Note the $\log _{10}$ scale of all axes.

showing that the endophyte effect on plants depends on growth conditions (Cheplick 2007). The relationship between reproductive biomass and seed number yielded a lower slope for endophyte-symbiotic plants than for non-symbiotic ones, when comparing the plants that grew under low and high nutrient availability. Low and high yielding endophytesymbiotic plants were found to be associated to a lower or a higher seed number, respectively. Although the endophyte effect on the trade-off between seed number and seed weight depended on the nutrient availability, the strongest effect was evidenced under high nutrient availability, where it did not reinforce the trade-off (since both biotypes had the same slope) but the relationship showed a higher intercept. When plotted together, the seed number/weight trade-off was lower for endophyte-symbiotic plants, indicating a narrower range for seed number than for seed weight. Thus, the endophyte seems to be associated with higher control on seed growth and development rather than with seed number. Maternal control should exist to limit competition among genetically different half-sibs in the plant in order to reconcile individual plant fitness with progeny fitness (Sadras \& Denison 2009). Fungal hyphae enter the ovary before flower fertilization and are still growing during seed development (Clay \& Schardl 2002). Therefore, there is a potential for the endophyte to control the individual seed through a competition-like mechanism (those seeds that start growing earlier become main sinks). On average, endophyte-symbiotic seed mass was $2.26 \mathrm{mg}$ (SE: $0.05, n=75$ ), while that of non-symbiotic seeds was $2.17 \mathrm{mg}$ (SE: $0.04, n=86$ ). Since the larger the seed the higher the fitness (Metz et al. 2010; Muller-Landau 2010), co-evolution between vertically transmitted endophytes and cool-season grasses could have promoted seed quality rather than quantity (Afkhami \& Rudgers 2008; Gundel et al. 2010).

The experiment comparing different host genotypes revealed that the effect of the vertically transmitted endophyte symbiont was highly dependent on the host genetic background. Symbiotic and non-symbiotic plants belonging to the original Pampean population did not show so much difference in both explored relationships (seed number/reproductive biomass, and seed number/weight) when growing under low nutrient availability. Alternatively, symbiotic and nonsymbiotic plant hybrids of a genetically distant population (Marshall) showed a marked difference in both relationships. Only when the endophyte was removed, inter-population hybrid plants expressed a higher reproductive biomass, probably as a result of hybrid vigor, and a strong trade-off between seed number and weight. On the contrary, symbiotic interpopulation hybrids behaved quite similarly to symbiotic and non-symbiotic Pampean plants under low level of resources, which expressed lower reproductive biomass and a less steep slope for the seed number/weight relationship. Under this condition, seed weight was $2.23 \mathrm{mg}$ (SE: $0.01, n=11$ ) for endophyte-symbiotic inter-population hybrid plants and $1.97 \mathrm{mg}$ (SE: $0.05, n=26$ ) for non-symbiotic inter-population hybrid plants. Even though gene flow may promote higher seed production and heavier hybrid seeds (Harper 1977), our results suggest that the endophyte own benefit may control the expression of hybrid vigor in plants. This possibility should be further investigated testing crosses with different populations, considering that ecological scenarios, in which plants are pollinated by pollen from genetically distant populations, are expected to be quite frequent for a wind-pollinated obligate allogamous (Gundel et al. 2010), and the consequences of reducing hybrid vigor should have importance for host fitness.

Since the entire life cycle of Neotyphodium fungi occurs within host plants, a tight connection between both organisms is established (Clay \& Schardl 2002; Saikkonen et al. 2004). Moreover, our approach is particularly valuable when applied to annual species, since it allows to determine the fate of all carbon fixed by an individual during its whole life (Smith \& Fretwell 1974; Niklas 1994; Cheplick 2002; Weiner 2004). While seed production is the main fitness trait for annual species (Harper 1977; Cheplick 2002), endophyte fitness also depends on vertical transmission efficiency (Afkhami \& Rudgers 2008; Gundel et al. 2008). Lack of light seeds in endophyte-symbiotic plants should reflect the endophyte effect promoting seed size, with light seeds being 
eliminated (early abortion of flowers, ovaries or seeds) by the competition of heavier endophyte-symbiotic seeds in the plant. Furthermore, a similar mechanism could explain the lack of endophyte in light seeds produced by extremely lowyielding plants and consequently, explaining the observed variations in the vertical transmission efficiency of Neotyphodium endophyte (Gundel, Garibaldi, Martínez-Ghersa, \& Ghersa 2011).

\section{References}

Afkhami, M. E., \& Rudgers, J. A. (2008). Symbiosis lost: Imperfect vertical transmission of fungal endophytes in grasses. American Naturalist, 172, 405-416.

Bonser, S. P., \& Aarssen, L. W. (2009). Interpreting reproductive allometry: Individual strategies of allocation explain size-dependent reproduction in plant populations. Perspectives in Plant Ecology, 11, 31-40.

Cheplick, G. P. (2002). Size and architectural traits as ontogenetic determinants of fitness in a phenotypically plastic annual weed (Amaranthus albus). Plant Species Biology, 17, 71-84.

Cheplick, G. P. (2007). Costs of fungal endophyte infection in Lolium perenne genotypes from Eurasia and North Africa under extreme resource limitation. Environmental and Experimental Botany, 60, 202-210.

Clay, K., \& Schardl, C. (2002). Evolutionary origin and ecological consequences of endophyte symbiosis with grasses. American Naturalist, 160, 99-127.

Faeth, S. H. (2002). Are endophytic fungi defensive plant mutualists? Oikos, 98, 25-36.

Faeth, S. H. (2009). Asexual fungal symbionts alter reproductive allocation and herbivory over time in their native perennial grass hosts. American Naturalist, 173, 554-565.

Gundel, P. E., Batista, W. B., Texeira, M., Martínez-Ghersa, M. A., Omacini, M., \& Ghersa, C. M. (2008). Neotyphodium endophyte infection frequency in annual grass populations: Relative importance of mutualism and transmission efficiency. Proceedings of the Royal Society of London B, 275, 897-905.

Gundel, P. E., Garibaldi, L. A., Martínez-Ghersa, M. A., \& Ghersa, C. M. (2011). Neotyphodium endophyte transmission to Lolium multiflorum seeds depends on the host plant fitness. Environmental and Experimental Botany, 71, 359-366.

Gundel, P. E., Omacini, M., Sadras, V. O., \& Ghersa, C. M. (2010). The interplay between the effectiveness of the grass-endophyte mutualism and the genetic variability of the host plant in an agronomic context. Evolutionary Applications, 3(5-6), 538-546.
Harper, J. (1977). Population biology of plants. Elsevier Science \& Technology Books.

Metz, J., Liancourt, P., Kigel, J., Harel, D., Sternberg, M., \& Tielbörger, K. (2010). Plant survival in relation to seed size along environmental gradients: A long-term study from semi-arid and Mediterranean annual plant communities. Journal of Ecology, 98(3), 697-704.

Muller-Landau, H. C. (2010). The tolerance-fecundity trade off and the maintenance of diversity in seed size. Proceedings of the National Academy of Science of the United States of America, 107, 4242-4247.

Niklas, K. J. (1994). Plant allometry. The scaling of form and process. University of Chicago Press.

R Development Core Team. (2011). R: A language and environment for statistical computing. Vienna, Austria: R Foundation for Statistical Computing., ISBN 3-900051-07-0 http://www.Rproject.org

Sadras, V. O. (2007). Evolutionary aspects of the trade-off between seed size and number in crops. Field Crop Research, 100, 125-138.

Sadras, V. O., \& Denison, R. F. (2009). Do plant parts compete for resources? An evolutionary perspective. New Phytologist, 183, $565-574$.

Saikkonen, K., Wäli, P., Helander, M., \& Faeth, S. H. (2004). Evolution of endophyte-plant symbioses. Trends in Plant Science, 9, 275-280.

Smith, C. C., \& Fretwell, S. D. (1974). The optimal balance between size and number of offspring. American Naturalist, 108, 499-506.

Thompson, J. N. (2005). The geographic mosaic of coevolution. Chicago, IL: University of Chicago Press.

Venable, L. D. (1992). Size-number trade-offs and the variation of seed size with plant resource status. American Naturalist, 140(2), 287-304.

Vila-Aiub, M. M., Gundel, P. E., \& Ghersa, C. M. (2005). Fungal endophyte infection changes growth attributes in Lolium multiflorum Lam. Austral Ecology, 30, 49-57.

Weiner, J. (2004). Allocation, plasticity and allometry in plants. Perspective in Plant Ecology, 6(4), 207-215.

Weiner, J., Campbell, L. G., Pino, J., \& Echarte, L. (2009). The allometry of reproduction within plant populations. Journal of Ecology, 97, 1220-1233.

White, J. F., Jr., \& Torres, M. S. (2010). Is plant endophyte-mediated defensive mutualism the result of oxidative stress protection? Physiologia Plantarum, 138, 440-446.

Zhang, Q., Zhang, L., Weiner, J., Tang, J., \& Chen, X. (2011). Arbuscular mycorrhizal fungi alter plant allometry and biomass-density relationships. Annals of Botany, 107, 407-413.

\section{Available online at www.sciencedirect.com}

\section{SciVerse ScienceDirect}

